\title{
Intestinal Microflora of Rockfish Sebastes schlegeli, Tiger Puffer Takifugu rubripes and Red Grouper Epinephelus akaara at their Larval and Juvenile Stages
}

\author{
Varin Tanasomwang* and Kiyokuni Muroga* \\ (Received March 23, 1989)
}

\begin{abstract}
Investigations on the aerobic bacterial flora in the intestine of larval and juvenile stages of rockfish Sebastes schlegeli, tiger puffer Takifugu rubripes and red grouper Epinephelus akaara were carried out in relation to the microflora of ambient waters and feeds.

The numbers of bacteria on ZoBell's $2216 \mathrm{e}$ agar in the intestine of rockfish $(6-18 \mathrm{~mm}$ in total length), tiger puffer $(4-21 \mathrm{~mm})$ and red grouper $(5-15 \mathrm{~mm})$ ranged from $6.0 \times 10^{3}$ to 3.1 $\times 10^{8}, 8.6 \times 10^{4}$ to $2.4 \times 10^{8}$, and $1.4 \times 10^{8}$ to $2.6 \times 10^{5} \mathrm{CFU} / \mathrm{fish}$, respectively. A distinct decrease in the bacterial numbers was observed in a group of rockfish when their feeds were changed from live diets (rotifer, brine shrimp and/or copepods) to artificial diet and minced fish. The level of bacterial counts were $10^{4}, 10^{7}-10^{8}, 10^{3}, 10^{4} \mathrm{CFU} / \mathrm{ml}$ or $\mathrm{g}$ respectively in water, live diets, minced fish and artificial diet.

The intestinal microflora of rockfish and tiger puffer was characterized by predominating groups of Vibrio, Acinetobacter and Pseudomonas, while that of red grouper was comprised almost exclusively of Vibrio. However, the incidence of vibrios was much reduced in the group of rockfish which were fed rotifers medicated with sodium nifurstyrenate. The bacterial composition in the intestine of these fishes was found influenced by the microflora of foods ingested rather than ambient water.
\end{abstract}

During the last decade, significant advances have been made in mass seed production of marine fishes in Japan. These efforts were placed since the establishment of the 200-mile Exclusive Economic Zone reduced Japanese marine catch of economically valuable species and natural seed resources for farming were limited. ${ }^{1,2)}$ At present, seed production techniques have been developed for about 40 species $^{3)}$ represented by red sea bream Pagrus major, black sea bream Acanthopagrus schlegeli and Japanese flounder Paralichthys olivaceus. More than 50 millions of juveniles of these marine fishes are produced annually in governmental and private hatcheries in order to stock feral populations for fishing and to supply seedlings for commercial culture in net cages. ${ }^{2}$ )

The mass seed production of marine fishes is now relying significantly on nutritionally supplemented rotifer Brachionus plicatilis and brine shrimp Artemia salina for their larval feeds.") However, high mortalities of fish larvae with abnormalities in the digestive tracts have often occurred. Although these mortali- ties have been ascribed to some species of the genus Vibrio, ${ }^{6-8)}$ the problems remain unresolved. In order to elucidate the pathogenesis of these intestinal infections studies on the intestinal miroflora of normal fish seem to be essential. Following our previous works in sea breams and Japanese flounder, ${ }^{\theta, 10)}$ the intestinal bacterial floras of rockfish Sebastes schlegeli, tiger puffer Takifugu rubripes and red grouper Epinephelus akaara at their larval and juvenile stages in relation to the microflora of diets and ambient waters were investigated in the present study.

\section{Materials and Methods}

\section{Fish Samples}

Rockfish were sampled at Hiroshima Prefectural Fisheries Experimental Station (HPFES), Ondo, Hiroshima Prefecture. Samples were taken once a week from rearing tank 1, 2 and a cage from April 20 to June 8, 1987 as shown in Table 1. In order to prevent bacterial infections, medicated rotifers, which were

* Faculty of Applied Biological Science, Hiroshima University, Higashi-Hiroshima 724, Japan (Varin Tanasomwang, 室賀清邦: 広島大学生物生産学部). 
Table 1. Sampling data of rockfish taken at HPFES*1

\begin{tabular}{lcccccc}
\hline $\begin{array}{c}\text { Sampling } \\
\text { date } \\
(1987)\end{array}$ & $\begin{array}{c}\text { Days } \\
\text { after } \\
\text { delivery }\end{array}$ & $\begin{array}{c}\text { Total } \\
\text { length } \\
(\mathrm{mm})\end{array}$ & $\begin{array}{c}\text { Water } \\
\text { tempe- } \\
\text { rature } \\
\left({ }^{\circ} \mathrm{C}\right)\end{array}$ & $\begin{array}{c}\text { Amount } \\
\text { of fish } \\
\text { examined } \\
\text { g } \times \text { groups }\end{array}$ \\
\hline Tank 1 & & & & & & \\
April 20 & 0 & 6.0 & 15.8 & $0.1(45) * 2 \times 3$ \\
& 27 & 7 & 7.4 & 16.2 & $0.1(18)$ & $\times 2$ \\
May & 4 & 14 & 10.8 & 17.9 & $0.1(7)$ & $\times 3$ \\
& 11 & 21 & 13.7 & 18.9 & $0.5(14)$ & $\times 3$ \\
& 18 & 28 & 17.7 & 18.0 & $0.5(9)$ & $\times 3$ \\
Tank 2 & & & & & \\
April 27 & 10 & 9.2 & 17.5 & $0.1(12)$ & $\times 3$ \\
May & 4 & 17 & 12.0 & 16.4 & $0.1(5)$ & $\times 3$ \\
& 11 & 24 & 14.9 & 17.5 & $0.5(12)$ & $\times 3$ \\
& 18 & 31 & 17.0 & 17.6 & $0.5(7)$ & $\times 3$ \\
Cage & & & & & & \\
June & 1 & & 15.7 & 22.0 & $0.5(10)$ & $\times 3$ \\
& 8 & & 20.5 & 21.5 & $0.5(4)$ & $\times 3$ \\
\hline
\end{tabular}

*1 Hiroshima Prefectural Fisheries Experimental Station.

-2 Average number of fish in one group.

Table 2. Sampling data of tiger puffer taken at HPFES*1

\begin{tabular}{|c|c|c|c|c|c|}
\hline $\begin{array}{c}\text { Sampling } \\
\text { date } \\
(1987)\end{array}$ & $\begin{array}{l}\text { Days } \\
\text { after } \\
\text { hatching }\end{array}$ & $\begin{array}{l}\text { Total } \\
\text { length } \\
\text { (mm) }\end{array}$ & $\begin{array}{l}\text { Water } \\
\text { tempe- } \\
\text { rature } \\
\left({ }^{\circ} \mathrm{C}\right)\end{array}$ & \multicolumn{2}{|c|}{$\begin{array}{l}\text { Amount } \\
\text { of fish } \\
\text { examined } \\
\mathrm{g} \times \text { groups }\end{array}$} \\
\hline \multicolumn{6}{|l|}{ Tank 1} \\
\hline May 25 & 6 & 3.6 & 20.0 & $0.1(78)^{* 2}$ & $\times 3$ \\
\hline June & 13 & 5.2 & 21.8 & $0.1(21)$ & $\times 3$ \\
\hline 8 & 20 & 8.4 & 21.0 & $0.1(7)$ & $\times 3$ \\
\hline 15 & 27 & 11.0 & 18.9 & $0.5(13)$ & $\times 3$ \\
\hline 22 & 34 & 14.0 & 21.5 & $0.5(8)$ & $\times 3$ \\
\hline 29 & 41 & 21.0 & 22.0 & $0.5(3)$ & $\times 3$ \\
\hline \multicolumn{6}{|l|}{ Tank 2} \\
\hline June 1 & 14 & 6.0 & 21.7 & $0.1(19)$ & $\times 3$ \\
\hline 8 & 21 & 9.1 & 20.8 & $0.1(6)$ & $\times 3$ \\
\hline 15 & 28 & 12.4 & 18.9 & $0.5(12)$ & $\times 3$ \\
\hline 22 & 35 & 15.0 & 21.0 & $0.5(7)$ & $\times 3$ \\
\hline 29 & 42 & 21.0 & 22.0 & $0.5(3)$ & $\times 3$ \\
\hline
\end{tabular}

*1 Hiroshima Prefectural Fisheries Experimental Station.

*2 Average number of fish in one group.

immersed in $5 \mu \mathrm{g} / \mathrm{ml}$ of sodium nifurstyrenate (NFS-Na) for $5 \mathrm{~h}$, were given to the larvae reared in tank $1\left(25 \mathrm{~m}^{8}\right)$ for 33 days after delivery. In addition to the medicated rotifers, brine shrimp, wild collected copepods and artificial diets were supplied from days 8,13 and 23 on, respectively. Fish stocked in tank 2 $\left(1 \mathrm{~m}^{3}\right)$ were fed non-medicated rotifers as well as brine shrimp. Samples were also taken from a cage in which relatively older fish were fed artificial diets and minced fish.
Table 3. Sampling data of red grouper taken at OPFFC $^{* 1}$ and JASFA*2

\begin{tabular}{|c|c|c|c|c|}
\hline $\begin{array}{c}\text { Sampling } \\
\text { date }\end{array}$ & $\begin{array}{c}\text { Days } \\
\text { after } \\
\text { hatching }\end{array}$ & $\begin{array}{c}\text { Total } \\
\text { length } \\
\text { (mm) }\end{array}$ & $\begin{array}{l}\text { Water } \\
\text { tempe- } \\
\text { rature } \\
\left({ }^{\circ} \mathrm{C}\right)\end{array}$ & $\begin{array}{c}\text { Amount } \\
\text { of fish } \\
\text { examined } \\
\text { No. } \times \text { groups }\end{array}$ \\
\hline \multicolumn{5}{|l|}{ OPFFC } \\
\hline $\begin{array}{c}\text { August } \\
1986\end{array}$ & 17 & 4.4 & 26.4 & $20 \times 3$ \\
\hline 26 & 36 & 15.1 & 28.0 & $10 \times 3$ \\
\hline \multicolumn{5}{|c|}{ JASFA (Tamano) } \\
\hline$\underset{1987}{\text { August }}$ & 12 & 4.6 & 26.5 & $20 \times 4$ \\
\hline 12 & 20 & 7.8 & 26.4 & $20 \times 4$ \\
\hline
\end{tabular}

Tiger puffer samples from two rearing tanks $\left(10 \mathrm{~m}^{3}\right)$ at HPFES were examined weekly from May 25 to June 29, 1987 (Table 2). The fish in tank 1 were diploids, and those in tank 2 were triploids. ${ }^{11)}$ Feeding schedule consisted of rotifers from day 2 after hatching until day 25 , collected copepods from day 13 to 34 , brine shrimp from day 26 and minced fish from day 31 on. The fish were raised in the tanks for about 45 days until they reached $21-22 \mathrm{~mm}$ in total length.

Red grouper were sampled at two different stations in Okayama Prefecture, Okayama Prefectural Fish Farming Center (OPFFC) on August 7 and 26, 1986 and Tamano Station of Japan Sea-Farming Association (JASFA) on August 4 and 12, 1987 (Table 3). At OPFFC, the fish were fed rotifers from day 2 after hatching until day 30 , artificial diet and brine shrimp from day 15 on. At JASFA, foods supplied to the fish included rotifers from day 2 and artificial diet from day 10 on.

\section{Bacteriological Examination}

The intestinal microflora of larvae and juveniles were examined according to the isolation technique described by Muroga et al. ${ }^{\text {) }}$ Groups of fish by weight or by number (see Table 1-3) were immersed in $0.1 \%$ benzalkonium chloride for $1 \mathrm{~min}$ and rinsed thoroughly under tap water for $30 \mathrm{~s}$ to remove the surface bacteria. Then, the samples were homogenized aseptically with $0.85 \%$ saline in a glass homogenizer. Serially 10 -fold diluted samples of $0.1 \mathrm{ml}$ were spread onto ZoBell's 2216e and BTB teepol agar (Eiken Chemical Co., Ltd.) media to determine total aerobic bacterial population and abundance of vibrios, respectively. Water and 
feed samples were simultaneously examined. After incubation at $25^{\circ} \mathrm{C}$ for $48 \mathrm{~h}$, colony forming units (CFU) on the two media were enumertated and the colonies on ZoBell agar were sorted into several types according to their morphology. The proportions of 4 to $6 \mathrm{domi}-$ nant types to total CFU were recorded and of less dominant ones were put together into "others". The representative colonies for dominant types from all sources were submitted to taxonomical analysis. A total of 347 isolates (169 from rockfish, 115 from tiger puffer and 63 from red grouper) was tested for 35 characteristics. The examinations included colony and cell morphology, Gram stain, motility, production of oxidase and catalase, growth in peptone waters with various concentrations of $\mathrm{NaCl}$, Hugh-Leifson test, acid and gas production from several sugars, arginine, lysine and ornithine decarboxylation, nitrate reduction, gelatin liquefaction, indole and $\mathrm{H}_{2} \mathrm{~S}$ production, MR and VP tests, citrate utilization (Simmons) and ONPG test. The identification was based on the scheme described by Muroga et al. ${ }^{\mathrm{g})}$ and Bergey's Manual of Systematic Bacteriology Vol. 1.12)

\section{Results}

Bacterial Counts and Flora of Fish

Bacterial counts of rockfish at different total

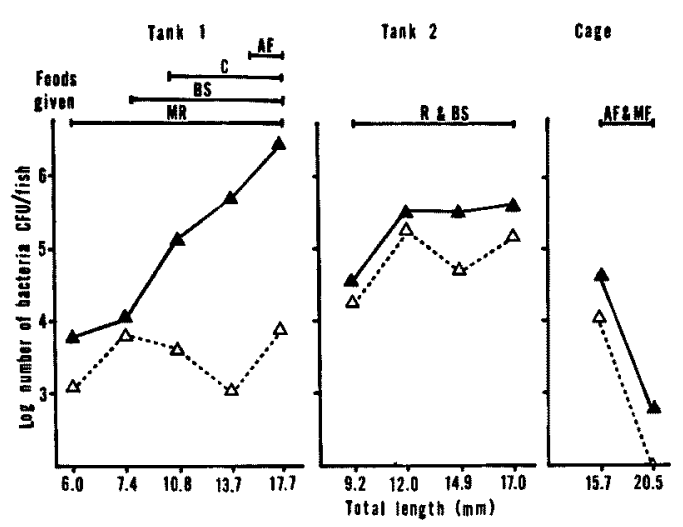

Fig. 1. Bacterial counts in the intestine of larval and juvenile rockfish. $\Delta-\Delta$ : count on ZoBell, $\triangle--\triangle$ : count on BTB, MR: medicated rotifer, $\mathrm{R}$ : rotifer, BS: brine shrimp, C: copepods, AF: artificial feed, MF: minced fish.

lengths are illustrated in Fig. 1. In tank 1 where 4 kinds of feeds including medicated rotifers were supplied, the counts of aerobic bacteria on ZoBell agar increased from $6.0 \times$ $10^{3} \mathrm{CFU} /$ fish in $6.0 \mathrm{~mm}$ larvae to $3.1 \times 10^{8} \mathrm{CFU} /$ fish in $17.7 \mathrm{~mm}$ juveniles. However, the bacterial numbers on BTB teepol agar of the same fish group remained relatively stable at $10^{3}$ $\mathrm{CFU} /$ fish, which was about 10 - to 100 - times lower than those in tank 2 where non-medicated rotifers were given. A remarkable de-

Table 4. Percentage bacterial flora of rockfish at different total lengths

\begin{tabular}{|c|c|c|c|c|c|c|c|c|c|c|}
\hline \multirow{2}{*}{$\begin{array}{c}\text { Total } \\
\text { length } \\
(\mathrm{mm})\end{array}$} & & \multicolumn{9}{|c|}{ Flora $(\%)$} \\
\hline & & A & B & $\mathrm{C}$ & D & $\mathrm{E}$ & $\mathbf{F}$ & $\mathbf{G}$ & $\mathbf{H}$ & I \\
\hline \multicolumn{11}{|l|}{ Tank 1} \\
\hline 6.0 & & & & & 41.1 & 50.9 & & & & 8.0 \\
\hline 7.4 & & 2.1 & & & 74.1 & & & & & 23.8 \\
\hline 10.8 & & 17.4 & 24.3 & & 27.5 & 29.0 & & & & 1.8 \\
\hline 13.7 & & & 2.3 & & 94.4 & 3.3 & & & & \\
\hline 17.7 & & 0.3 & 0.9 & & 2.2 & 96.1 & & & & 0.5 \\
\hline & Mean & 4.0 & 5.5 & & 47.9 & 35.9 & & & & 6.8 \\
\hline \multicolumn{11}{|c|}{ Tank 2} \\
\hline 9.2 & & & & 7.0 & 61.0 & & & 14.8 & & 17.2 \\
\hline 12.0 & & 86.2 & & & 11.6 & & & & & 2.2 \\
\hline 14.9 & & 22.7 & 38.5 & & & 36.8 & & 1.2 & & 0.8 \\
\hline 17.0 & & 31.7 & 2.2 & & 1.6 & 64.0 & & & & 0.5 \\
\hline & Mean & 35.1 & 10.2 & 1.8 & 18.5 & 25.2 & & 4.0 & & 5.2 \\
\hline \multicolumn{11}{|l|}{ Cage } \\
\hline 15.7 & & 43.6 & & & 19.4 & & 34.2 & & & 2.8 \\
\hline 20.5 & & & & & & 4.7 & 62.0 & & 19.0 & 14.3 \\
\hline & Mean & 21.8 & & & 9.7 & 2.4 & 48.1 & & 9.5 & 8.5 \\
\hline
\end{tabular}


crease in the bacterial counts on both media were observed in the fish fed artificial diets and minced fish in the cage. The intestinal microflora (Table 4) of the fish in tank 1 was characterized by Pseudomonas (47.9\%), Acinetobacter $(35.9 \%)$ and Vibrio $(9.5 \%)$, while in tank 2 Vibrio $(47.1 \%)$ predominated and was followed by Acinetobacter (25.2\%) and Pseudomonas $(18.5 \%)$. Members of Moraxella appeared to be the most dominant $(48.1 \%)$ in fish reared in the cage.

Table 5 shows the bacterial counts and flora of tiger puffer. Almost the same level of bacterial populations was obtained at any size of fish examined. The mean values from the two tanks were $1.6 \times 10^{5}$ and $4.0 \times 10^{\circ} \mathrm{CFU} /$ fish for ZoBell counts and $8.6 \times 10^{4}$ and $2.7 \times 10^{6}$ CFU/fish for BTB counts. With respect to the bacterial types, Vibrio constituted a major component of the fish flora $(55.8 \%$ and $57.4 \%$ for tank 1 and 2, respectively). Acinetobacter (27.4\% and 25.8\%) and Pseudomonas (13.8\% and $12.9 \%$ ) were the next important genera present.

In the case of red grouper (Table 6), the level of viable bacteria on ZoBell agar was calculated as $3.9 \times 10^{4} \mathrm{CFU} / \mathrm{fish}$ at OPFFC and $4.7 \times 10^{3} \mathrm{CFU} /$ fish at JASFA. The bacterial levels obtained on BTB agar were almost equal to those of the ZoBell counts. At the same time, high proportion of vibrios was found associated with the fish intestine, representing

Table 5. Bacterial counts and flora of tiger puffer at different total lengths

\begin{tabular}{|c|c|c|c|c|c|c|c|c|c|}
\hline \multirow{2}{*}{$\begin{array}{c}\text { Total } \\
\text { length } \\
(\mathrm{mm})\end{array}$} & \multicolumn{2}{|c|}{ Bacterial count (CFU/fish) } & \multicolumn{7}{|c|}{ Flora $(\%)^{*}$} \\
\hline & ZoBell & BTB & A & B & $\mathrm{C}$ & D & $\mathbf{E}$ & $\mathbf{F}$ & $\mathbf{G}$ \\
\hline \multicolumn{10}{|l|}{ Tank 1} \\
\hline 3.6 & $1.1 \times 10^{5}$ & $1.0 \times 10^{4}$ & 7.6 & 2.5 & & & 88.9 & & 1.0 \\
\hline 5.2 & $1.5 \times 10^{5}$ & $1.3 \times 10^{5}$ & 40.7 & & & 15.3 & 41.4 & & 2.6 \\
\hline 8.4 & $1.4 \times 10^{5}$ & $6.2 \times 10^{4}$ & 24.3 & 27.6 & & 4.6 & 34.2 & 2.6 & 6.5 \\
\hline 11.0 & $8.6 \times 10^{4}$ & $2.6 \times 10^{4}$ & 58.0 & & 41.2 & & & & 0.8 \\
\hline 14.0 & $1.5 \times 10^{5}$ & $2.4 \times 10^{5}$ & 21.0 & & 49.1 & 29.9 & & & \\
\hline 21.0 & $5.3 \times 10^{3}$ & $8.2 \times 10^{3}$ & & & 62.9 & 33.0 & & & 4.1 \\
\hline Mean & $1.6 \times 10^{5}$ & $8.6 \times 10^{4}$ & 25.3 & 5.0 & 25.5 & 13.8 & 27.4 & 0.4 & 2.5 \\
\hline \multicolumn{10}{|l|}{ Tank 2} \\
\hline 6.0 & $1.5 \times 10^{5}$ & $2.0 \times 10^{4}$ & 6.2 & 3.1 & & 10.4 & 79.8 & & 0.5 \\
\hline 9.1 & $9.9 \times 10^{5}$ & $2.7 \times 10^{5}$ & 22.6 & 16.1 & & 2.8 & 49.3 & 3.2 & 6.0 \\
\hline 12.4 & $1.8 \times 10^{3}$ & $3.0 \times 10^{5}$ & 46.3 & & 42.5 & 3.7 & & & 7.5 \\
\hline 15.0 & $1.6 \times 10^{5}$ & $2.6 \times 10^{5}$ & 29.2 & & 64.6 & 4.6 & & & 1.6 \\
\hline 21.0 & $2.4 \times 10^{8}$ & $3.6 \times 10^{8}$ & & & 56.9 & 43.1 & & & \\
\hline Mean & $4.0 \times 10^{5}$ & $2.7 \times 10^{5}$ & 20.8 & 3.8 & 32.8 & 12.9 & 25.8 & 0.6 & 3.1 \\
\hline
\end{tabular}

A: Vibrio spp. (I, II and II), B: V. anguillarum, C: V. alginolyticus, D: Pseudomonas, E: Acinetobacter, F: Cytophaga, G: Others.

* Determined on the basis of bacterial isolation on ZoBell agar.

Table 6. Bacterial counts and flora of red grouper sampled at two stations (OPFFC and JASFA)

\begin{tabular}{|c|c|c|c|c|c|c|c|}
\hline \multirow{2}{*}{$\begin{array}{l}\text { Total length } \\
(\mathrm{mm})\end{array}$} & \multicolumn{2}{|c|}{ Bacterial count (CFU/fish) } & \multicolumn{5}{|c|}{ Flora $(\%)^{*}$} \\
\hline & ZoBell & BTB & A & B & $\mathrm{C}$ & $\mathrm{D}$ & $\mathbf{E}$ \\
\hline \multicolumn{8}{|l|}{ OPFFC } \\
\hline 7.4 & $5.8 \times 10^{3}$ & $2.4 \times 10^{8}$ & 71.7 & & 28.3 & & \\
\hline \multirow[t]{2}{*}{15.1} & $2.6 \times 10^{5}$ & $4.0 \times 10^{3}$ & 93.0 & & 2.3 & & 4.7 \\
\hline & $3.9 \times 10^{4}$ & $3.1 \times 10^{4}$ & 82.4 & & 15.3 & & 2.4 \\
\hline \multicolumn{8}{|l|}{ JASFA (Tamano) } \\
\hline 4.6 & $1.4 \times 10^{8}$ & $5.2 \times 10^{2}$ & 67.6 & & 5.6 & 14.9 & 11.9 \\
\hline 7.8 & $1.6 \times 10^{4}$ & $9.2 \times 10^{3}$ & 77.1 & 20.6 & & & 2.3 \\
\hline Mean & $4.7 \times 10^{8}$ & $2.2 \times 10^{8}$ & 72.4 & 10.3 & 2.8 & 7.5 & 7.1 \\
\hline
\end{tabular}


$82.4 \%$ and $82.7 \%$ of the total flora for the two stations, respectively.

\section{Bacterial Counts and Flora of Ambient Water and Feeds}

Examinations of the water samples taken from each rearing unit (Table 7) revealed that the average bacterial numbers in tank water were nearly constant regardless of fish species, $1.3-7.8 \times 10^{4} \mathrm{CFU} / \mathrm{ml}$ on ZoBell agar and 2.2 $\times 10^{8}-2.2 \times 10^{4} \mathrm{CFU} / \mathrm{ml}$ on BTB agar. These figures were comparatively higher than those of water in the cage. Regarding the bacterial flora, some differences in the distribution of the genera were evidenced. Moraxella, Pseudomonas and Vibrio (except for tank 1) dominated in the rearing waters of rockfish and tiger puffer, whereas Pseudomonas was the most common organism in that of red grouper.

The results of the bacterial examination of feeds (Table 8) indicated that the live diets (rotifer, brine shrimp or copepods) contained the highest bacterial populations, ranging from $10^{7}$ to $10^{8} \mathrm{CFU} / \mathrm{g}$ except for the BTB count of the rotifers medicated with NFS-Na. There were marked differences in the bacterial com-

Table 7. Mean bacterial counts and flora of rearing water of rockfish, tiger puffer and red grouper

\begin{tabular}{|c|c|c|c|c|c|c|c|c|c|}
\hline & \multicolumn{2}{|c|}{$\begin{array}{l}\text { Bacterial count } \\
\text { (CFU/m } l)\end{array}$} & \multicolumn{7}{|c|}{ Flora $(\%)^{*}$} \\
\hline & ZoBell & BTB & $\mathbf{A}$ & $\mathbf{B}$ & $\mathrm{C}$ & D & $\mathbf{E}$ & $\mathrm{F}$ & $\mathrm{G}$ \\
\hline \multicolumn{10}{|l|}{ Rockfish } \\
\hline Tank 1 & $7.8 \times 10^{4}$ & $4.6 \times 10^{3}$ & 1.6 & 28.9 & 1.4 & 59.8 & & 2.7 & 5.6 \\
\hline Tank 2 & $6.8 \times 10^{4}$ & $1.1 \times 10^{4}$ & 23.2 & 26.9 & & 39.1 & 2.0 & & 8.8 \\
\hline Cage & $3.2 \times 10^{3}$ & $5.5 \times 10^{2}$ & 24.8 & 20.4 & & 37.0 & & & 17.8 \\
\hline \multicolumn{10}{|l|}{ Tiger puffer } \\
\hline Tank 1 & $5.0 \times 10^{4}$ & $2.2 \times 10^{4}$ & 29.0 & 23.6 & 8.4 & 26.4 & 0.7 & & 12.0 \\
\hline Tank 2 & $2.4 \times 10^{4}$ & $9.7 \times 10^{3}$ & 41.2 & 14.2 & 13.1 & 22.1 & 3.5 & & 5.8 \\
\hline \multicolumn{10}{|l|}{ Red grouper } \\
\hline Tank (OPFFC) & $1.9 \times 10^{4}$ & $9.1 \times 10^{3}$ & 22.2 & 74.1 & & 2.3 & & & 1.5 \\
\hline Tank (JASFA) & $1.3 \times 10^{4}$ & $2.2 \times 10^{3}$ & 8.9 & 48.5 & & 21.8 & 14,0 & & 6.8 \\
\hline
\end{tabular}

A: Vibrio, B: Pseudomonas, C: Acinetobacter, D: Moraxella, E: Cytophaga, F: Alcaligenes, G: Others

- Determined on the basis of bacterial isolation on ZoBell agar.

Table 8. Mean bacterial counts and fora of feeds for rockfish, tiger puffer and red grouper

\begin{tabular}{|c|c|c|c|c|c|c|c|c|c|c|}
\hline \multirow{2}{*}{ Feed } & \multicolumn{2}{|c|}{ Bacterial count ( $\mathrm{CFU} / \mathrm{g})$} & \multicolumn{8}{|c|}{ Flora $(\%)^{* 1}$} \\
\hline & ZoBell & BTB & A & B & $\mathrm{C}$ & D & $\mathrm{E}$ & $\mathrm{F}$ & G & $\mathbf{H}$ \\
\hline \multicolumn{11}{|l|}{ Rockfish } \\
\hline Medicated rotifer & $1.7 \times 10^{8}$ & $1.7 \times 10^{8}$ & 4.5 & 8.2 & 48.0 & 31.7 & & & & 7.6 \\
\hline Rotifer & $6.3 \times 10^{8}$ & $1.2 \times 10^{8}$ & 11.8 & 15.4 & 23.3 & 20.8 & 17.4 & & & 11.3 \\
\hline Brine shrimp & $2.0 \times 10^{8}$ & $1.8 \times 10^{8}$ & 29.9 & 44.9 & & & 5.1 & 4.7 & 5.3 & 10.1 \\
\hline Artificial feed & $1.1 \times 10^{5}$ & $1.4 \times 10^{3}$ & & & 47.7 & & & & 49.3 & 3.0 \\
\hline Minced fish & $4.3 \times 10^{5}$ & $3.9 \times 10^{4}$ & & 16.6 & 21.1 & 8.1 & & & 42.1 & 12.1 \\
\hline \multicolumn{11}{|l|}{ Tiger puffer } \\
\hline Rotifer & $4.1 \times 10^{8}$ & $8.4 \times 10^{7}$ & 6.5 & 21.4 & 59.9 & & 5.6 & & & 6.6 \\
\hline Brine shrimp & $5.4 \times 10^{8}$ & $5.0 \times 10^{8}$ & 59.8 & 33.9 & & & & & & 6.3 \\
\hline Copepods & $2.5 \times 10^{7}$ & $\mathrm{ND}^{* 2}$ & 43.0 & 25.7 & & 12.5 & 6.2 & & & 12.6 \\
\hline Minced fish & $1.1 \times 10^{5}$ & $6.9 \times 10^{3}$ & & & 25.2 & 64.2 & & & & 10.6 \\
\hline \multicolumn{11}{|l|}{ Red grouper } \\
\hline Rotifer & $7.2 \times 10^{7}$ & $1.5 \times 10^{7}$ & 35.9 & 49.1 & & & 11.3 & & & 3.9 \\
\hline Brine shrimp & $5.0 \times 10^{8}$ & $1.3 \times 10^{3}$ & 32.0 & 56.0 & & & & & & 12.0 \\
\hline Artificial feed & $1.7 \times 10^{4}$ & $1.0 \times 10^{2}$ & & & & & & & 94.1 & 5.9 \\
\hline
\end{tabular}

A; Vibrio, B: Pseudomonas, C: Acinetobacter, D: Maraxella, E: Cytophaga, F: Alcaligenes, G: Gram-positive bacteria, H: Others.

*1 Determined on the basis of bacterial isolation on ZoBell agar.

*2 Not determined. 
position even in the same kind of diet. In rotifers given to rockfish at HPFES, Acinetobacter $(48.0 \%$ and $23.3 \%$ respectively for medicated and non-medicated) and Moraxella (31.7\% and $20.8 \%$ ) were the predominant organisms, followed by Pseudomonas $(8.2 \%$ and $15.4 \%)$ and Vibrio (4.5\% and $11.8 \%$ ). Acinetobacter (59.9\%), Pseudomonas (21.4\%) Vibrio (6.5\%) and Cytophaga (5.6\%) were recorded in rotifers given to tiger puffer at HPFES, while Pseudomonas (49.1\%), Vibrio (35.9\%) and Cytophaga (11.3\%) occurred in those for red grouper at Okayama stations. The microflora of brine shrimp and copepods exhibited a similar generic pattern, which was composed principally of Vibrio and Pseudomonas. In contrast to the live diets, Gram-positive bacteria predominated $(49.3-94.1 \%)$ in artificial feed. Gram-positive bacteria $(42.1 \%)$ were again isolated from minced fish given to rockfish in addition to Acinetobacter, Pseudomonas and Moraxella, but only Moraxella $(64.2 \%)$ and Acinetobacter $(25.2 \%)$ were recovered from minced fish for tiger puffer.

\section{Discussion}

The intestinal microflora of marine fish has been extensively studied on a variety of species in widely different geographic locations. However, most of these data were concerned with the microflora of adult fish, either wild or cultured, and related to spoilage or nutritional aspects. ${ }^{18-19)}$ Little information is available on the gut flora of fish at their larval and juvenile stages except for farmed Dover sole ${ }^{20)}$ and our previous works. ${ }^{\theta, 10)}$

The present study supports our earlier observations in sea breams and Japanese flounder $r^{\theta, 10}$ in view of the fact that the intestinal microflora of larval and juvenile stages in marine fish is derived both quantitatively and qualitatively from foods ingested. During the early larval stage, the most prevalent bacteria in the intestine, Acinetobacter in rockfish and tiger puffer and Vibrio in red grouper, reflected the bacterial flora of their initial food, rotifers. Subsequently, when brine shrimp and/or copepods were supplied as supplemental diets, a remarkable increase in the incidence of Vibrio was apparent in these fishes, but it was not in the group of rockfish which were fed rotifers medicated with sodium nifurstyrenate (NFS-
$\mathrm{Na}$. This suggests that NFS-Na, the most commonly used chemotherapeutic agent in hatcheries, might suppress the multiplication of Vibrio associated with either the rotifers or fish intestine. The effect of this chemotherapeutant in reducing the number of vibrios in rotifers was confirmed in our previous investigation. ${ }^{21}$ A distinct decrease in the intestinal bacterial numbers was observed in the rockfish when their feeds were changed from live diets to artificial diet and minced fish. Low bacterial populations in the artificial diet and minced fish as compared to the live diets must have affected the number of intestinal flora of the fish. On the other hand, the relationships between the intestinal bacterial flora of these fishes and their ambient waters were less clear.

As previously mentioned, the intestinal infections associated with Vibrio alginolyticus in sea breams ${ }^{b, 0)}$ and Vibrio sp. INFL group in Japanese flounder ${ }^{7,8)}$ have been reported as devastating problems in seed production process. In the present study, $V$. alginolyticus was isolated from all species of fish examined. $V$. anguillarum, a well known fish pathogen, was also isolated from rockfish and tiger puffer, although none of the isolates belonged to $\mathrm{J}-0-1$, 2 or 3 serotypes (data not presented). However, no correlation was seen between the appearance of these bacteria and fish mortality in the present cases. In the next step, the interaction between the pathogenic vibrios like Vibrio sp. INFL group $^{8)}$ and normal bacterial flora including Vibrio, Pseudomonas, Acinetobacter, Moraxella and Cytophaga should be studied both in vitro and in vivo.

\section{Acknowledgements}

This work was supported by the Ministry of Education, Science and Culture of Japan grant No. 61440018. We wish to thank the staffs of Hiroshima Prefectural Fisheries Experimental Station, Okayama Prefectural Fish Farming Center and Tamano Station of Japan SeaFarming Association for facilitating the supply of fish specimens.

\section{References}

1) O. Fukuhara: NOAA Tech. Rep. 10, 3-9 (1978).

2) O. Fukuhara: NOAA Tech. Rep. 47, 1-2 (1987).

3) W. D. Nagata and H. Hirata: Mini Rev. Data File Fish. Res., 4, 1-38 (1986). 
4) T. Watanabe, C. Kitajima, and S. Fujita: Aquaculture, 34, 115-143 (1983).

5) K. Iwata, Y. Yanohara, and O. Ishibashi: Fish Pathol, 13, 97-102 (1978).

6) R. Kusuda, J. Yokoyama, and K. Kawai: Nippon Suisan Gakkaishi, 52, 1745-1751 (1986).

7) O. Murata: Fish Pathol., 22, 59-61 (1987).

8) K. Masumura, H. Yasunobu, N. Okada, and K. Muroga: Fish Pathol, 24, (in press) (1989).

9) K. Muroga, M. Higashi, and H. Keitoku: Aquaculture, 65, 79-88 (1987).

10) V. Tanasomwang and K. Muroga: Fish Pathol., 23, 77-83 (1988).

11) C. E. Purdom: Aquaculture, 33, 287-300 (1983).

12) N. R. Krieg and J. G. Holt: Bergey's Manual of Systematic Bacteriology, Vol. 1, William and Wilkins, Baltimore, USA, 1984, pp. 1-964.
13) J. Liston: J. gen. Microbiol., 16, 205-216 (1957).

14) R. R. Colwell: J. appl. Bact., 25, 147-158 (1962).

15) K. Aiso, U. Simidu, and K. Hasuo: J. gen. Microbiol., 52, 361-364 (1968).

16) J. T. Newman, B. J. Cosenza, and J. D. Buck: J. Fish. Res. Bd. Can., 29, 333-336 (1972).

17) H. Sera and Y. Ishida: Nippon Suisan Gakkaishi, 38, 853-858 (1972).

18) T. Sakata, M. Nakaji, and D. Kakimoto: Mem. Fac. Fish, Kagoshima Univ., 27, 65-71 (1978).

19) N. L. MacDonald, J. R. Stark, and B. Austin: FEMS Microbiol. Lett., 35, 107-111 (1986).

20) A. C. Campbell and J. A. Buswell: J. appl. Bact., 55, 215-223 (1983).

21) V. Tanasomwang and K. Muroga: Fish Pathol., 24, 29-35 (1989). 